\title{
Treatment of High-strength CFB-QP Forged Parts by Stepwise Water Quenching
}

Štěpán Jeníček, Ivan Vorel, Michal Peković

Regional Technological Institute, University of West Bohemia in Pilsen, Univerzitní 22, 30614 Plzeň. Czech Republic. E-mail: jeniceks@rti.zcu.cz, frost@rti.zcu.cz, pekovicm@rti.zcu.cz, vkotesov@rti.zcu.cz

The forging industry, and the production of high-strength forged parts in particular, saw no substantial progress in recent decades. High-strength parts continued to be made of well-tried steel grades which meet the economic and environmental production requirements, using mainly the conventional quenching and tempering. However, the latest findings in physical metallurgy of higher-silicon steels suggest that high-strength forgings can also be obtained by producing bainitic and martensitic microstructures. The first are of the CFB (carbide-free bainite) type and the latter comprise the QP (quenching-partitioning) microstructure. At greatly reduced processing costs, properties comparable to tempered martensite can thus be attained.

Keywords: CFB-QP forgings, bainite, QP martensite, retained austenite, TRIP effect

\section{Introduction}

Reducing production costs, improving the environmental aspects of production and high safety are among the fundamental indicators which characterize the operation of forge shops. Today, the manufacture of forged parts comprises operations related to forging and heat treatment [1]. This heat treatment of forged parts, typically normalizing or quenching and tempering, is often very costly but necessary for grain refinement and homogenization or for improving strength properties provided by quenched and tempered martensitic microstructure. In forge shops, the total heat treatment time of forged parts is generally between several hours and tens of hours, depending on the material, type of treatment, temperature and the part's size.

High-strength quenched and tempered forgings with a microstructure of tempered martensite are today's highend forging products $[2,3]$. Thanks to the latest findings in physical metallurgy of forged parts, a new generation of forged parts can be added to the class of high-strength forgings. Their microstructure consists of unconventional CF (carbide-free) bainite and QP martensite [4,5]. An important feature of the use of CFB-QP forged parts is their energy-efficient nature which, together with their strength and deformation parameters which equal or exceed typical characteristics of tempered martensite in conventional forging steels, promises considerable savings in the production costs of high-strength forged products.

The basis of the processing of CFB-QP forged parts uses some aspects of the austenite decomposition into bainite-type structures upon cooling to the bainitic nose region. The austenite-bainite transformation in conventional forging steels for high-strength forged products, such as the $42 \mathrm{CrMo} 4$ grade, involves the following reaction:

austenite $\rightarrow$ bainitic ferrite + cementite

As this thermodynamic system has zero degrees of freedom, it should be equivalent to the eutectoid pearlitic transformation of austenite which is accompanied by a heavily exothermic reaction and a temperature plateau. Based on this marked similarity between pearlitic and bainitic transformations in conventional steels, one can expect the bainitic transformation to be exothermic as well. In thermodynamic terms, the austenite decomposition into bainite in CFB-QP forgings is very similar to the above reaction. Its products, however, are as follows:

$$
\text { austenite } \rightarrow \text { bainitic ferrite }+ \text { retained austenite }
$$

It follows that formation of the CFB should be exothermic as well, i.e. releasing internal heat. This heat can be effectively used for processing the CFB-QP forged parts, leading to great reductions in post-forge operation times and energy demands. Another aspect of importance is microstructural evolution in CFB-QP forged parts. Their microstructure consists of a majority of bainitic ferrite, QP martensite and retained austenite. Retained austenite, unlike cementite or complex carbides in conventional bainite, does not impair ductility. It improves the toughness of CFB forged products thanks to the TRIP effect.

\section{Experiments}

Based on certain assumptions and the knowledge of the course of the transformation of austenite to bainite, heat treatment sequences for a chosen forged part (Fig. 1) were designed.

The forged part is an automobile brake caliper. It is made of the standard 42CrMo4 forging steel (Tab.1). After progressive closed-die forging operations, the product is cooled in still air to room temperature and then normalized for 2 hours.

Normalizing is followed by quenching to room temperature and tempering at $300^{\circ} \mathrm{C}$ for 4 hours. This provides the forged part with strengths between 1000 and $1200 \mathrm{MPa}$, yield strength levels of 750-1000 MPa, and total elongation of $6-9 \%$. 

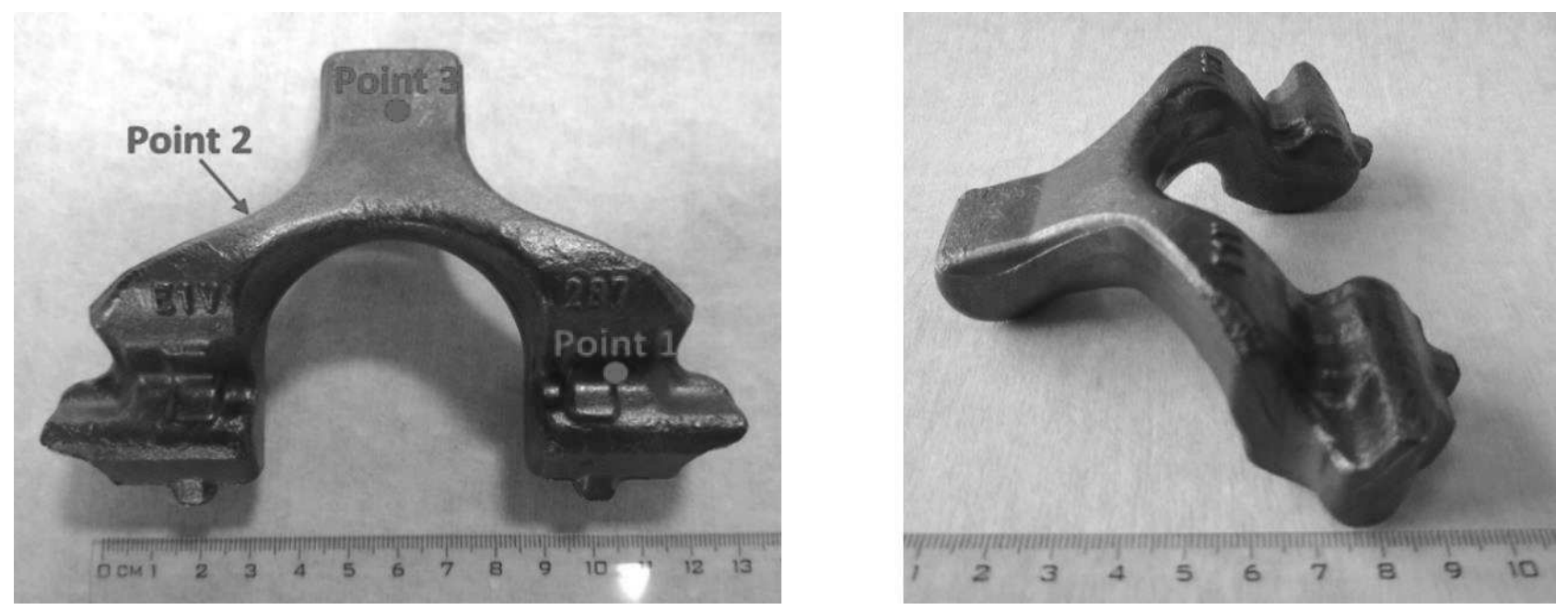

Fig. 1 Forged brake caliper and indicated thermocouple locations

Tab. 1 Chemical compositions of the 42CrMo4 conventional forging steel and $42 \mathrm{SiCr} \mathrm{CFB}$ steel

\begin{tabular}{|c|c|c|c|c|c|c|c|c|c|}
\hline & \multicolumn{7}{|c|}{ Chemical composition [weight \%] } & \\
\hline Steel designation & $\mathrm{C}$ & $\mathrm{Si}$ & $\mathrm{Mn}$ & $\mathrm{Cr}$ & $\mathrm{Mo}$ & $\mathrm{Nb}$ & $\mathrm{P}$ & $\mathrm{S}$ & $\mathrm{Ms}\left[{ }^{\circ} \mathrm{C}\right]$ \\
\hline $42 \mathrm{CrMo} 4$ & 0.43 & 0.25 & 0.60 & 1.2 & 0.15 & 0.001 & 0.009 & 0.025 & 310 \\
\hline $42 \mathrm{SiCr}$ & 0.43 & 2.03 & 0.59 & 1.33 & 0.16 & 0.03 & 0.005 & 0.003 & 305 \\
\hline
\end{tabular}

For the purpose of testing the substitution of today's high-strength forged parts treated to obtain tempered martensite with the processing of unconventional CFB-QP forgings, a small heat of unconventional steel designated as $42 \mathrm{SiCr}$ was manufactured and cast as a material for making demonstration forgings (Tab. 1). The demonstration forgings were machined from this steel using waterjet cutting according to accurate drawings. These forgings were then homogenized $\left(1100^{\circ} \mathrm{C} / 4 \mathrm{hrs}\right)$ and normalized $\left(950^{\circ} \mathrm{C} / 1 \mathrm{hr}\right)$ in argon gas. After thermocouples had been attached to them, they were heated in a furnace to $1250^{\circ} \mathrm{C}$ and then cooled in a water bath. The thermocouples were employed to monitor temperature during cooling. Three thermocouples were attached to each forged part at critical cross sections, i.e. those with the largest and smallest cross sectional area.

For the purpose of simulating the manufacturing route of the forged parts, the measured temperature-time histories were converted to material-technological models for

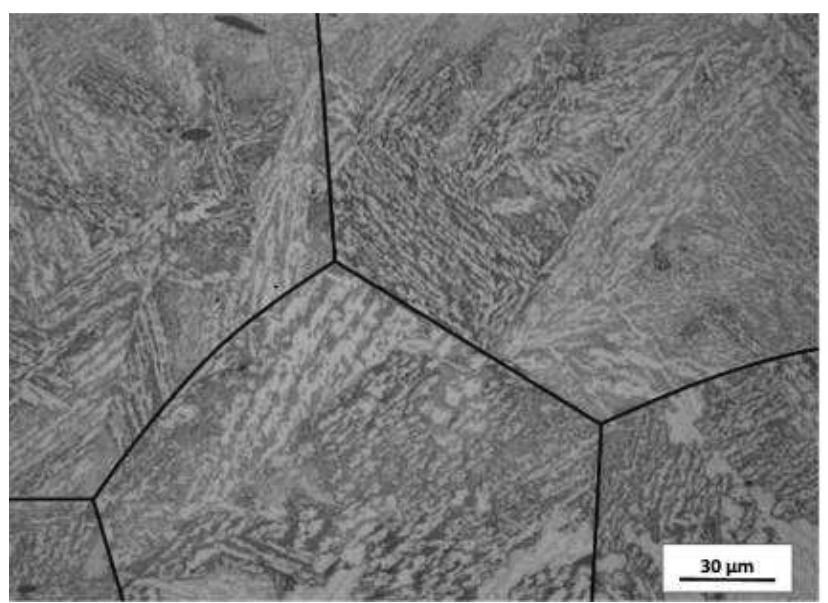

simulating the thermal cycles of the forged part: induction heating to the forging temperature of $1250^{\circ} \mathrm{C}$, cooling from the forging temperature, stepwise quenching in a water batch and cooling in still air [6]. Due to physical limitations, forging could not be simulated by materialtechnological modelling. Therefore, the microstructural response to forging deformation during cooling could not be explored. Instead, boundary conditions were introduced which in part reflected the effects of deformation. The first was the austenite grain size after forging. In the forged part of $42 \mathrm{CrMo} 4$, the prior austenite grain size after cooling in still air from the finishing temperature was in the range $80-240 \mu \mathrm{m}$ (Fig. 2). The microstructure was rather coarse from the technological standpoint. From this perspective, it is fair to assume that dynamic recrystallization dominated between the strengthening (plastic deformation) and softening (recrystallization) mechanisms.

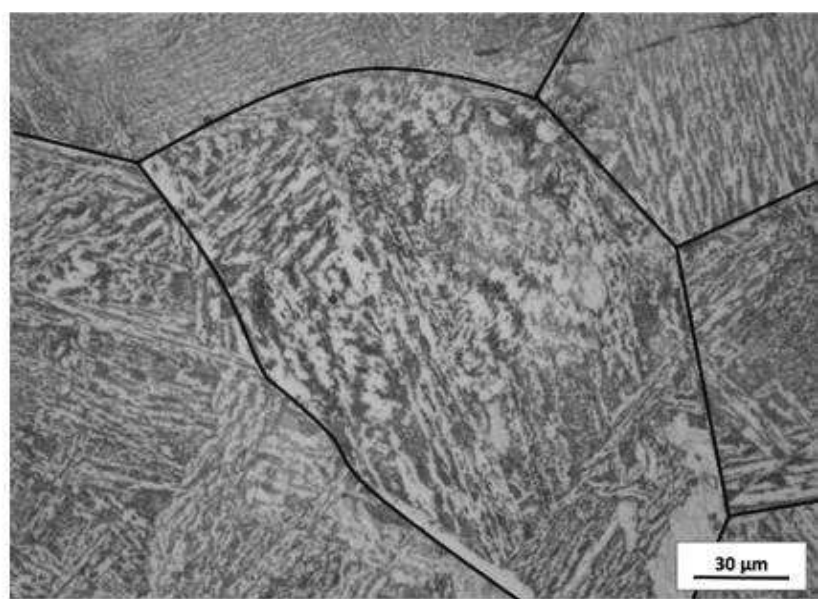

Fig. 2 Prior austenite grain size at monitored points on the cross section - 42CrMo4 steel - cooling in still air from the finishing temperature a) point 1 b) point 2 
From the viewpoint of the kinetics of the bainitic reaction, the prior austenite grain size considerably affects the rate of austenite decomposition to bainite. From the general perspective, one can say that with decreasing austenite grain size, the rate of growth of bainite increases because with more grain boundaries the bainite nucleation potential increases in the early stage of the bainitic transformation. On the other hand, however, it should be noted that comparable volume fractions of bainite are obtained with both fine-grained and coarse-grained austenite. The other boundary condition was the fact that dynamic recrystallization, which leads to severe grain coarsening, causes severe softening. This means that austenite is not stabilised by mechanical working prior to bainitic transformation, which would strongly suppress bainite nucleation on austenite grain boundaries.
Experimental processing was carried out in a thermomechanical simulator with induction-resistive heating [7]. Sheet samples with a gauge length of $20 \mathrm{~mm}$ and 1.5$\mathrm{mm}$ thickness were used as workpieces for processing and subsequent tensile testing. Prior to processing, they were homogenized and normalized in argon gas.

\subsection{Experimental processing CFB-QP 1}

The experiment involved modelling of an approximate thermal cycle of the forged part. It started with induction heating to the forging temperature of $1250^{\circ} \mathrm{C}$, followed by quenching of the forged part in water at room temperature for 15 seconds and subsequent cooling in still air (Fig. 3).

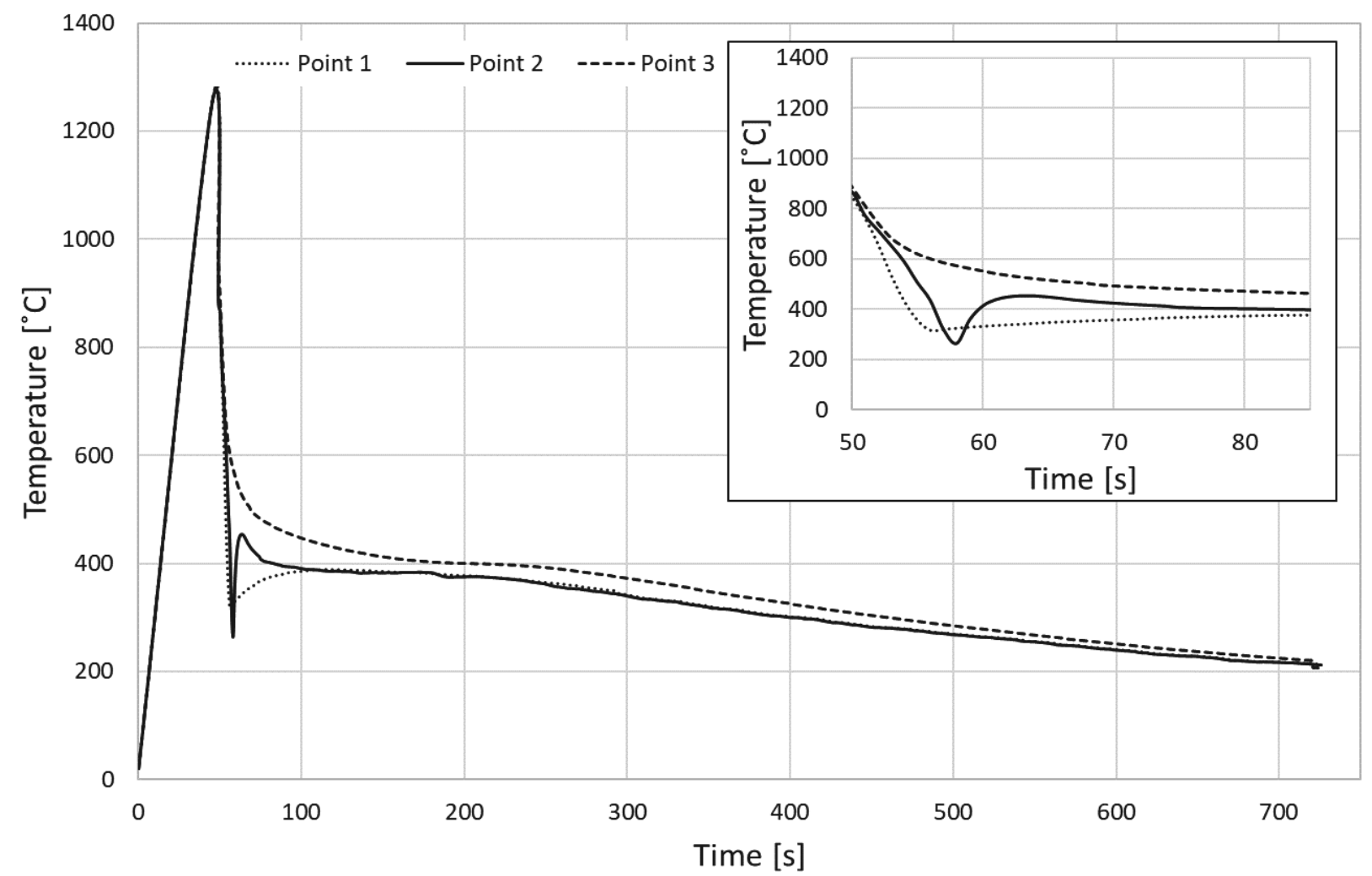

Fig. 3 Temperature-time profile of the heat treatment of the experimental forged part at monitored points 1, 2, 3-the $C F B-Q P 1$ process sequence

Differences between the temperature-time plots from thermocouples at individual locations on the forged part reflected the differences in the forged part's processing time. At point 2 of the forged part, the temperature after the above-specified quenching time was $260^{\circ} \mathrm{C}$, at point 1 it was approximately $320^{\circ} \mathrm{C}$ and at point 3 it was $560^{\circ} \mathrm{C}$. The measured temperature-time curves show an increase in temperature at points 1 and 2 after quenching. The likely reason is the internal heat which was conducted to these monitored areas from the thicker surrounding regions of the forged part and also resulted from the exothermic austenite decomposition.

This conclusion is corraborated by distinctive temperature plateaux seen in the right part of the temperature- time plots from individual thermocouples. CF bainite was detected in the microstructure using scanning electron microscopy. All samples processed according to materialtechnological models were found to contain a majority of $\mathrm{CF}$ bainite, fresh martensite and the M-A constituent (Fig. 4).

The lowest ultimate tensile strength (UTS) in the samples, which represented the monitored points on several cross sections of the forged part, was $1320 \mathrm{MPa}$ in the sample for point 3 . In the samples representing points 1 and 2, the UTS values were comparable, $1440 \mathrm{MPa}$ and $1450 \mathrm{MPa}$, respectively. The highest total elongation, $\mathrm{TE}_{20 \mathrm{~mm}}=12 \%$, was found in the sample processed according to the material-technological model of point 3 . The 
lowest value, $\mathrm{TE}_{20 \mathrm{~mm}}=9 \%$, was found in the sample representing the material-technological model of point 1 (Tab. 2).
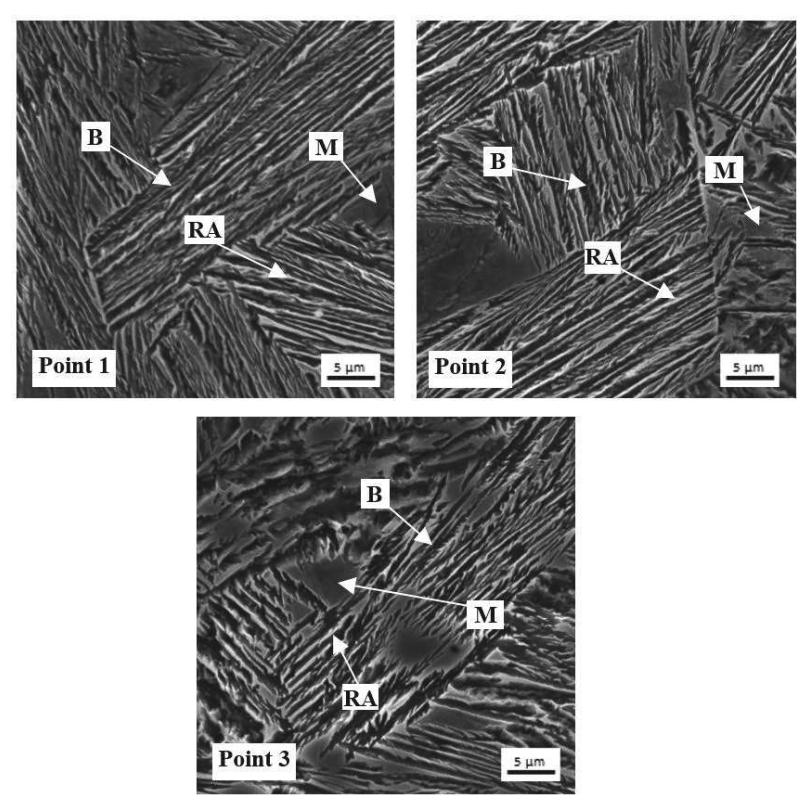

Fig. 4 Microstructures in samples representing material-technological models of points 1 through 3 -experimental processing $C F B-Q P$ 1, B-bainite, $R A$-retained austenite, $M$ - martensite
Tab. 2 Values of UTS, YS, TE $20 \mathrm{~mm}$ and YS/UTS in samples processed according to material-technological models of points 1 through 3 in the forged part-experimental processing $C F B-Q P 1$

\begin{tabular}{|l|c|c|c|c|}
\hline & $\begin{array}{c}\text { UTS } \\
{[\mathrm{MPa}]}\end{array}$ & $\begin{array}{c}\text { YS } \\
{[\mathrm{MPa}]}\end{array}$ & $\mathrm{TE}_{20 \mathrm{~mm}}$ & YS/UTS \\
\hline Point 1 & 1440 & 1200 & 9 & 0.83 \\
\hline Point 2 & 1450 & 1185 & 11 & 0.81 \\
\hline Point 3 & 1320 & 1060 & 12 & 0.80 \\
\hline
\end{tabular}

\subsection{Experimental processing CFB-QP 2}

The experimental processing B2 of the forged part involved modelling a thermal cycle that comprised heating to the forging temperature of $1250^{\circ} \mathrm{C}$ and subsequent two-step quenching in water bath (Fig. 5).

In the first step, the forged part was submerged in the bath for 10 seconds, and the temperatures at individual points were as follows: point $1: 800^{\circ} \mathrm{C}$, point $2: 520^{\circ} \mathrm{C}$, point 3: $900^{\circ} \mathrm{C}$. Afterwards, the forged part was removed from the bath and kept in air for 5 seconds, and then placed in the water bath again for 5 seconds, and then removed and cooled in still air. As the forged part was removed from the water bath for the second time, the temperature was $450^{\circ} \mathrm{C}$ at point 1 , but $260^{\circ} \mathrm{C}$ at point 2 and $520^{\circ} \mathrm{C}$ at point 3 .

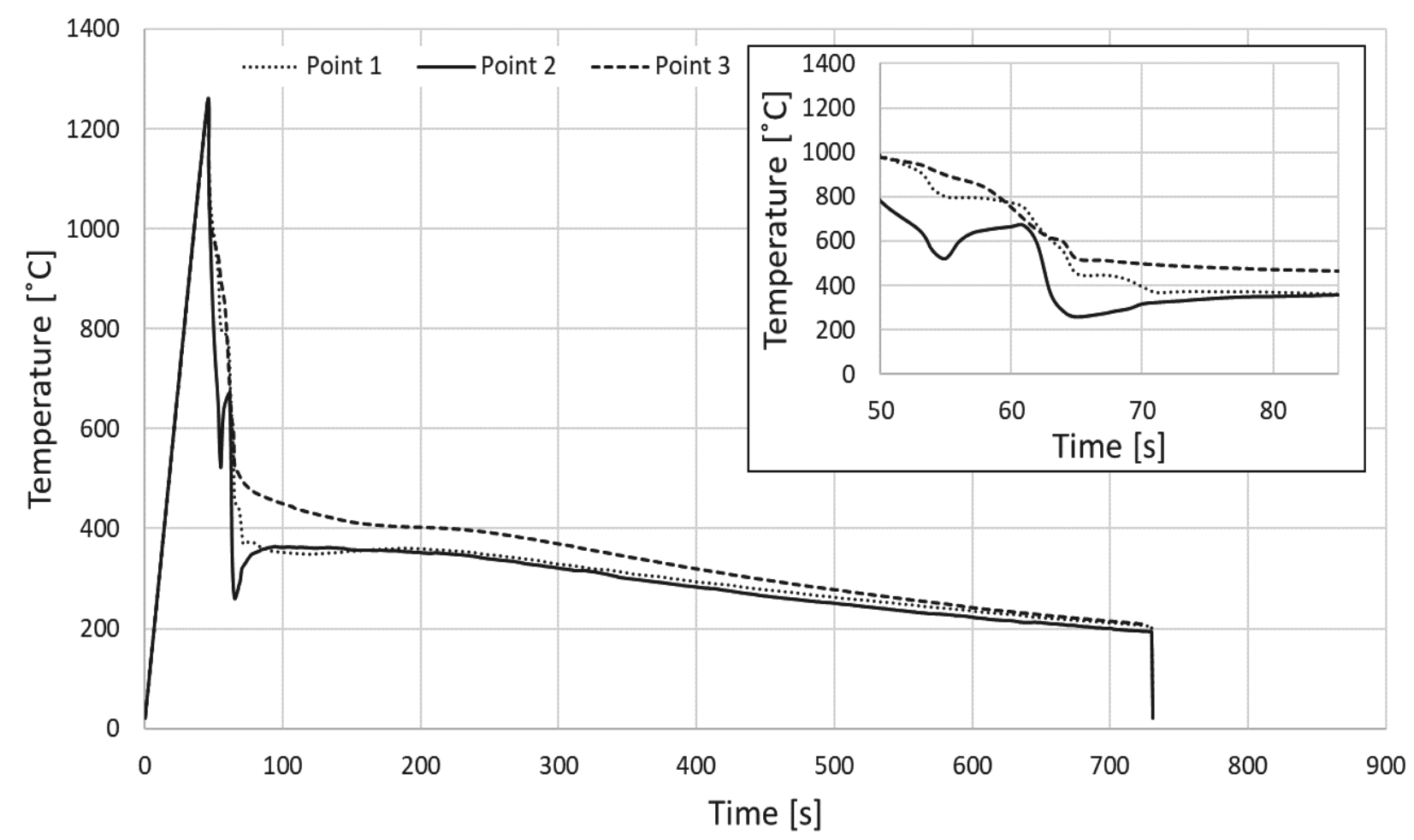

Fig. 5 Temperature-time plot of heat treatment of the experimental forged part at monitored points 1, 2, 3 -the CFBQP 2 processing sequence

The temperature-time plot for the processing of the forged part indicated a likely bainitic transformation during a partially isothermal plateau following the second water cooling step.

The microstructure of the sample processed according to the material-technological model which represented point 1 consisted mostly of CF bainite and a minority of the M-A constituent (Fig. 6). The microstructure of the sample processed according to the model of point 2 of the forged part consisted of what appeared to be tempered QP 
martensite and M-A constituent. In the case of the sample processed according to the material-technological model of point 3, a microstructure of CF bainite, M-A constituent and retained austenite was observed.

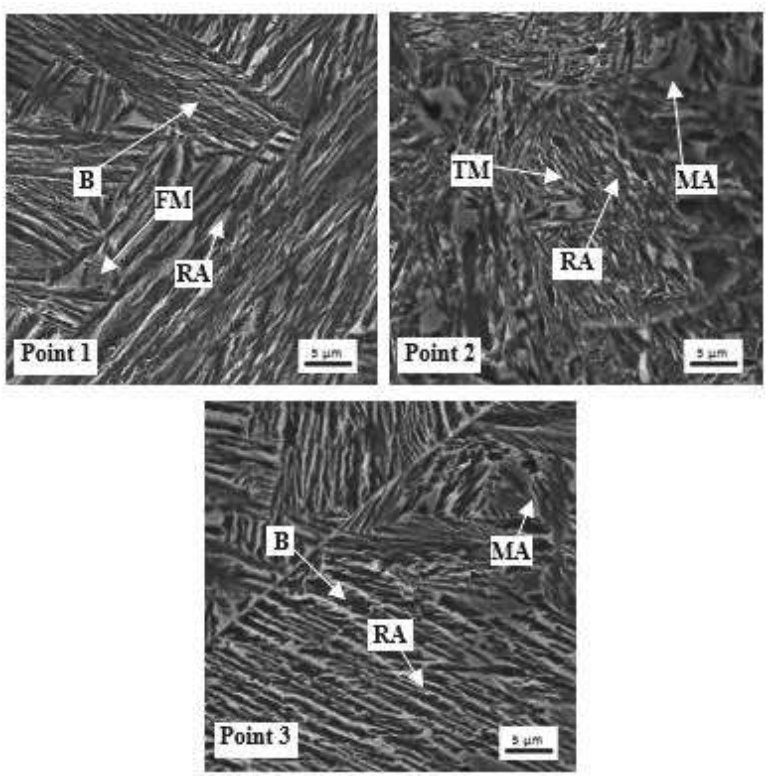

Fig. 6 Microstructure of the sample processed according to the material-technological model of point 3 -experimental processing $C F B-Q P 2$

$R A$ - retained austenite, TM - tempered martensite, MA - $M-A$ constituent

The lowest measured UTS value was found in the sample processed according to the material-technological model of point 3: UTS $=1330 \mathrm{MPa}$, together with the yield strength of $\mathrm{YS}=1050 \mathrm{MPa}$ and total elongation $\mathrm{TE}_{20 \mathrm{~mm}}=16 \%$ (Fig. 8). In the samples processed according to the material-technological models of points 1 and
2, the ultimate tensile strengths were UTS $=1560$ and $1570 \mathrm{MPa}$, respectively, the yield strengths were YS = 1250 and $1240 \mathrm{MPa}$, respectively, and the total elongation values were identical: $\mathrm{TE}_{20 \mathrm{~mm}}=12 \%(\mathrm{Tab} 3$.)

Tab. 3 Values of UTS, YS, TE $20 \mathrm{~mm}$ and YS/UTS for the samples processed according to material-technological models of points 1 through 3 in the forged parts - experimental processing $C F B-Q P 2$

\begin{tabular}{|l|c|c|c|c|}
\hline & $\begin{array}{c}\text { UTS } \\
{[\mathrm{MPa}]}\end{array}$ & $\begin{array}{c}\text { YS } \\
{[\mathrm{MPa}]}\end{array}$ & $\mathrm{TE}_{20 \mathrm{~mm}}$ & YS/UTS \\
\hline Point 1 & 1560 & 1250 & 12 & 0.80 \\
\hline Point 2 & 1570 & 1240 & 12 & 0.78 \\
\hline Point 3 & 1330 & 1050 & 16 & 0.78 \\
\hline
\end{tabular}

\subsection{Experimental processing CFB-QP 3}

The processing sequence of the experimental forged part consisted of heating to the forging temperature of $1250^{\circ} \mathrm{C}$ and subsequent stepwise cooling in water bath and air. In the first step, the forged part was submerged in the water bath for 13 seconds and then kept in air for 3 seconds (Fig. 7). Before it was removed from the water bath, the following temperatures had been recorded: point 1: $785^{\circ} \mathrm{C}$, point $2: 410^{\circ} \mathrm{C}$, point $3: 840^{\circ} \mathrm{C}$. In the second step, the forged part was submerged in water for 5 seconds and then left to cool in still air.

Interrupted quenching of the forged part in the second step of the sequence led to the following temperatures: point $1: 465^{\circ} \mathrm{C}$, point $2: 210^{\circ} \mathrm{C}$, point $3: 670^{\circ} \mathrm{C}$. Like in the above-discussed experimental processing sequences of the forged part, the temperature-time plots for the heat treatment of the forged part showed the progress of transformation of austenite which occurred in the lower range of the bainitic transformation temperature interval for the $42 \mathrm{SiCr}$ steel.

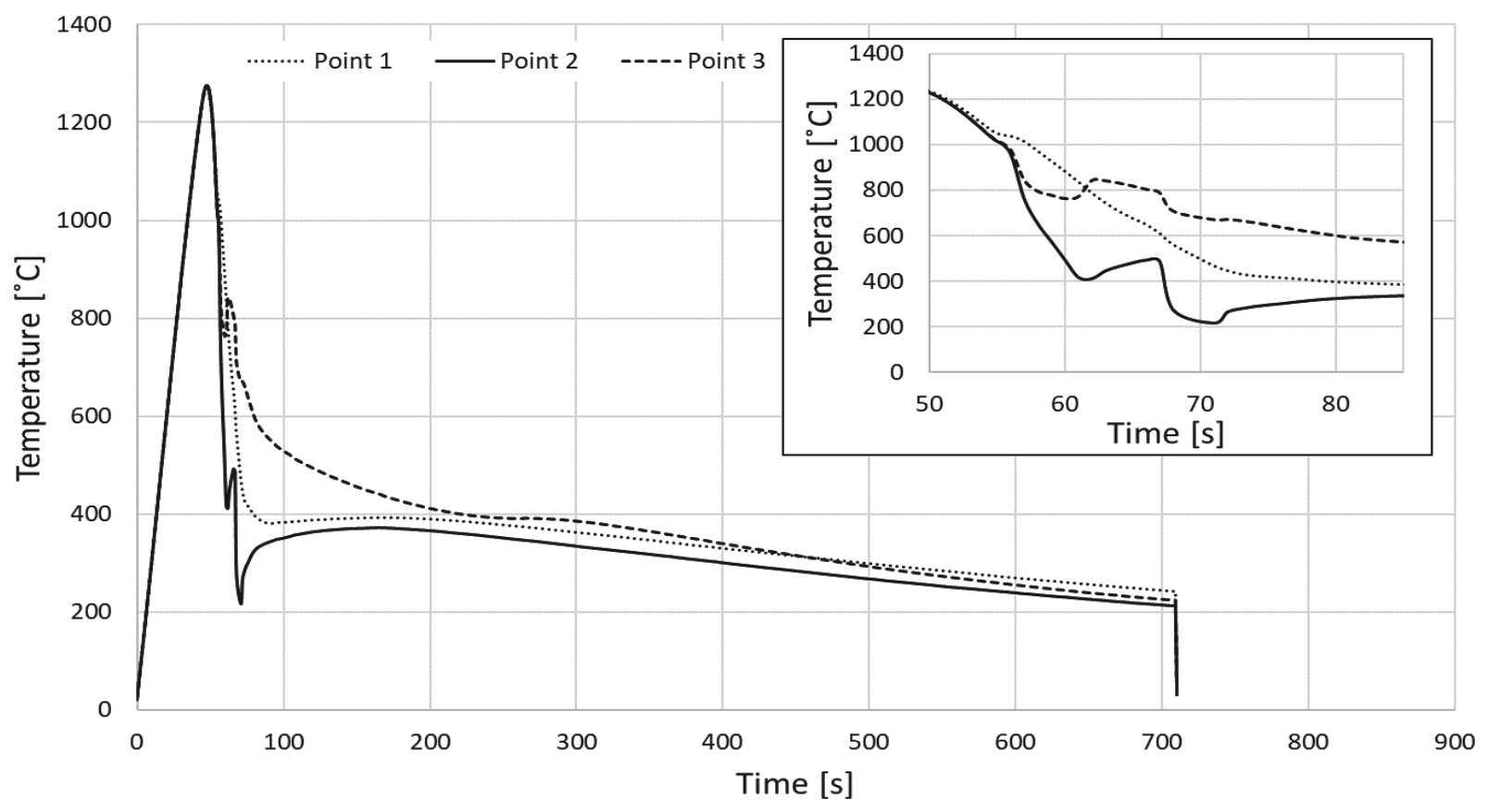

Fig. 7 Temperature-time profiles for the heat treatment of the experimental forged part at monitored points 1, 2, 3-the $C F B-Q P 3$ processing sequence 

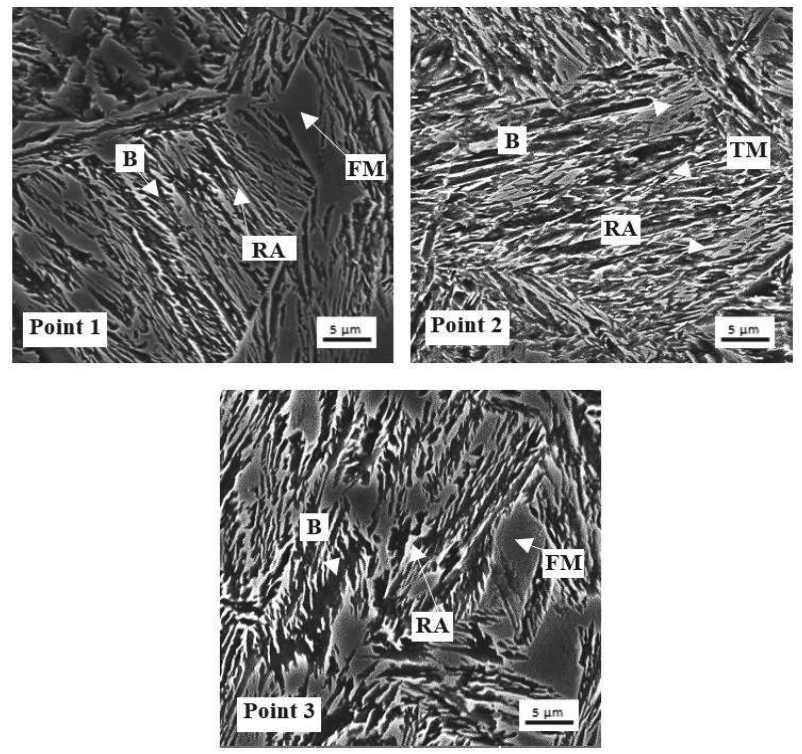

Fig. 8 Microstructure of the sample processed according to the material-technological model of point 3 -experimental processing $C F B-Q P 2$

$B$-bainite, $R A$ - retained austenite, TM - tempered martensite, FM-fresh martensite

The microstructure of the sample processed according to the material-technological model representing point 1 consisted mostly of CF bainite, retained austenite and a minority of the M-A constituent (Fig. 8). The microstructure of the sample processed according to the model of point 2 on the forged part consisted probably of tempered QP martensite, CF bainite and retained austenite. In the case of the sample processed according to the material-technological model of point 3, a microstructure of CF bainite, fresh martensite and retained austenite was observed.

Tab. 3 Values of UTS, YS, TE $20 \mathrm{~mm}$ and YS/UTS for samples processed according to material-technological models of points 1 through 3 in the forged part-experimental processing $C F B-Q P 3$

\begin{tabular}{|l|c|c|c|c|}
\hline & $\begin{array}{c}\text { UTS } \\
{[\mathrm{MPa}]}\end{array}$ & $\begin{array}{c}\text { YS } \\
{[\mathrm{MPa}]}\end{array}$ & $\mathrm{TE}_{20 \mathrm{~mm}}$ & YS/UTS \\
\hline Point 1 & 1490 & 1215 & 11 & 0.81 \\
\hline Point 2 & 1480 & 1190 & 10 & 0.80 \\
\hline Point 3 & 1355 & 1015 & 15 & 0.75 \\
\hline
\end{tabular}

Among the samples processed according to materialtechnological models representing the monitored points on cross sections through the forged part, the one with the lowest ultimate tensile strength (UTS) of $1355 \mathrm{MPa}$ was the one corresponding to the material-technological model of point 3. At points 1 and 2, the UTS values were comparable: $1490 \mathrm{MPa}$ and $1480 \mathrm{MPa}$, respectively. The yield strength at point 1 was $\mathrm{YS}=1215 \mathrm{MPa}$, at point 2 it was YS $=1190 \mathrm{MPa}$ and at point 3 it was $\mathrm{YS}=1015$ $\mathrm{MPa}$. The highest total elongation, $\mathrm{TE}_{20 \mathrm{~mm}}=15 \%$, was found in the sample processed according to the materialtechnological model of point 3 . The lowest value, $\mathrm{TE}_{20 \mathrm{~mm}}$ $=10 \%$, was found at point 2 (Tab. 4 ).

\section{Conclusion}

This investigation focused on the feasibility of substituting the conventional treatment of a forged brake caliper of 42CrMo4, which consisted of normalizing, quenching and tempering (tempered martensite), with a combination of quenching and cooling in still air applied to the $42 \mathrm{SiCr}$ unconventional steel, which would lead to a microstructure of CF (carbide-free) bainite and QP martensite. In order to verify the usability of the treatment of unconventional $\mathrm{CF}$ forged parts, demonstration forged parts of $42 \mathrm{SiCr}$ steel were manufactured. At critical points of their cross sections, thermocouples were attached for monitoring temperature during cooling from the forging temperature. Using the temperature plots obtained in this manner, physical models were created and employed for modelling temperature cycles which comprised induction heating to the forging temperature and subsequent stepwise quenching in water bath and cooling in still air in a thermomechanical simulator. The issues of deformation applied to the material during forging and dynamic recrystallization of the workpiece at high temperatures were neglected because measuring temperature at critical cross-section points of the forged parts using thermocouples would have been unfeasible. Upon considering this, simplifying assumptions were adopted on the basis of earlier experience with treatment of forged parts. One of them concerned the fact that the grain size at this forging temperature, $1250^{\circ} \mathrm{C}$, tends to be very large, between 80 and $240 \mu \mathrm{m}$. This is due to the interaction between the applied deformation, strain uniformity and dynamic recrystallization which plays a dominant role at these temperatures in the softening phenomena and grain coarsening. Furthermore, it was assumed that due to the high soaking temperature of the workpiece, dynamic recrystallization would prevent the deformation stabilization of austenite which would otherwise change the position of the curves in the CCT diagram.

It follows from these experiments that in all these experimental processing sequences for forged parts of unconventional $42 \mathrm{SiCr}$ steel with increased silicon content, internal heat was released after cooling in the regions of bainitic or martensitic transformation. This occurred in the more massive parts of the forged part, most probably due to the slightly exothermic nature of the austenite-bainite transformation. This phase transformation resulted in distinctive plateaux in the temperature-time curves in the regions of austenite decomposition into bainite, which showed a striking similarity to the isothermal plateaux which are seen, for instance, in pearlitic eutectoid transformations. On the thinnest cross-section of the forged part, where changes in temperature were monitored with respect to the stepwise cooling in the water bath, interrupted quenching below the $\mathrm{M}_{\mathrm{s}}$ temperature was applied, followed by stepwise tempering - a modified Q\&P process. The microstructures of samples processed according to material-technological models of the more massive portions of the forged parts consisted mostly of CF bainite, retained austenite and the M-A constituent or fresh martensite. In the samples processed according to material-technological models of the thinnest cross section, 
the microstructures comprised CF bainite, the M-A constituent or fresh martensite and retained austenite, which relates to those processing sequences in which the forged parts were removed from the water bath during stepwise quenching before reaching the $\mathrm{M}_{\mathrm{s}}$ temperature. The microstructure of the samples processed according to material-technological models of the thinnest cross section of forged parts, in which stepwise quenching led to incomplete quenching below the $\mathrm{M}_{\mathrm{s}}$ temperature, consisted of tempered martensite, retained austenite and bainite.

The ultimate tensile strengths (UTS) of the samples processed according to material-technological models were in the range of 1570-1290 MPa. The yield strength (YS) was in the range of 1250-790 MPa. Total elongation $\left(\mathrm{TE}_{20 \mathrm{~mm}}\right)$ reached the lowest value of $9 \%$ and the highest value of $20 \%$. From a general perspective, the above-reported static mechanical properties in of samples processed according to the material-technological models of CFB-QP forgings of the 42SiCr steel were comparable to the condition of forged parts of the conventional $42 \mathrm{CrMo} 4$ steel after normalizing, quenching and tempering. However, a major advantage of CFB-QP forgings which are stepwise-quenched from the forging temperature over conventional forged parts might be the significantly shorter production times and savings in manufacturing and operating costs. Therefore, the next step will involve experimental processing of forged parts in a forge shop using the unconventional $42 \mathrm{SiCr}$ steel and the above-described stepwise quenching from the forging temperature.

\section{Acknowledgement}

The present contribution has been prepared under project LO1502 'Development of the Regional Technological Institute' under the auspices of the National Sustainability Programme I of the Ministry of Education of the Czech Republic aimed to support research, experimental development and innovation.

\section{References}

[1] MAŠEK, B., JENÍČEK, Š., KÁŇA, J., VOREL, I. (2017). Budoucnost zpracování zápustkových výkovků z vysokopevných FF-AHS ocelí. Kovárenství, roč. 2017, č. 60, s. 54-57. ISSN: 1213-9289
[2] IBRAHIM, K., VOREL, I., BUBLÍKOVÁ, D., MAŠEK, B. (2016) New concept for manufacturing closed die forgings of high strength steels. Materiali in Technologije, roč. 50, č. 4, s. 623-626. ISSN: 1580-2949

[3] BUBLÍKOVÁ, D., MAŠEK, B., VOREL, I., JENÍČEK, Š. (2017) Stability of Retained Austenite in High-Strength Martensitic Steels with Low Ms Temperature. Manufacturing technology, roč. 17, č. 4, s. 428-433. ISSN: 1213-2489

[4] PEKOVIĆ, M., VOREL, I., KÁŇA, J., OPATOVÁ, K. (2017) Evolution of microstructure and mechanical properties in steels during isothermal holding in the region of bainitic transformation temperature in dependence on silicon content. Manufacturing Technology, roč. 17, č. 4/2017, s. 549-555. ISSN: 1213-2489

[5] KOTĚŠOVEC, V., VOREL, I., JENÍČEK, Š., KÁŇA, J., IBRAHIM, K. Impact of quenching temperature and isothermal holding time during austempering on bainite content in high-silicon steel. In IOP Conference Series-Materials Science and Engineering. Bristol: IOP PUBLISHING LTD, 2017. s. 1-5. ISBN: neuvedeno , ISSN: $1757-8981$

[6] VOREL, I., VANČURA, F., PILEČEK, V., JIRKOVÁ, H., MAŠEK, B. (2015) Material-technological Modelling of C45 Steel die Forgings. In 25th DAAAM International Symposium Intelligent Manufacturing \& Automation, 2014. Vienna: Procedia Engineering,. s. 714-721. ISBN: neuvedeno , ISSN: 1877-7058

[7] VOREL, I., JENÍČEK, ড̌., KÁŇA, KOTĚŠOVEC, V., (2018) Optimization of controlled cooling of forgings from finshing temperature with the use of light and electron microscopy, Manufacturing Technology, roč. 18, č. 1, s. 154159. ISSN: 1213-2489 